\title{
JEKK
}

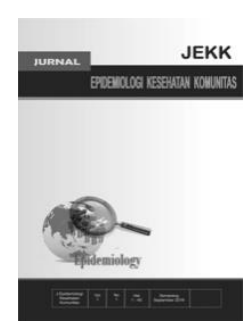

\section{Kolaborasi Perawat dan Ahli Gizi dalam Penanganan Masalah Gizi Balita di Wilayah Kerja Puskesmas Halmahera Barat}

\author{
Vilia Herani Noky*, Kristiani D. Tauho*, Kristiawan P.A Nugroho** \\ "Program Studi Ilmu Keperawatan, Fakultas Kedokteran dan Ilmu Kesehatan, Program Studi Ilmu Gizi, \\ Fakultas Kedokteran dan Ilmu Kesehatan, Universitas Kristen Satya Wacana
}

\begin{abstract}
Background: Nutritional status is the body's needs in the growth and development of toddlers. study on nutrition development in Indonesia shows that the problem of child nutrition is still high in the community. North Maluku Province is the fourth place among the provinces which contributing nutrition problem in 2019 (20.9\%). Good nutritional status itself is necessary to the growth and the development of toddlers. Since the number of nutritionists in North Maluku Province is still limited, this study was conducted to explore the collaboration between nutritionists and nurses in handling nutritional problems among toddlers in this province.
\end{abstract}

Methods: This study used a qualitative research method and was conducted in 5 Primary Health Care Centers within the region of West Halmahera District. This research involved 15 participants consisting of nurses, nutritionists and the Heads of Primary Health Care Center. The data collection used in-depth interviews for each participant with a total of research duration of about 2 months.

Result: The results showed that the collaboration between nurses and nutritionists was mainly to perform vital body examination and to give supplementary feeding for toddlers. Primary Health Care has a Plan of Action for this program of collaboration. Other than that, sometimes they provide some health education about exclusive breastfeeding, good nutritional intake and the importance of bringing toddlers to the integrated service center called Posyandu.

Conclusion : Nurses and nutritionists in West Halmahera collaborate to improve toddlers nutritional status but the collaboration is still limited.

Keywords: Nurse; nutritionist; toddlers.

*Penulis korespondensi, kristiawan.nugroho@uksw.edu 


\section{Pendahuluan}

Zat gizi adalah suatu kebutuhan tubuh yang diperlukan dalam pertumbuhan dan perkembangan balita. Pada usia 0-2 tahun masa tumbuh kembang balita (bayi dan anak dibawah lima tahun) sangat optimal terutama untuk pertumbuhan jaringan otak sehingga perlu diperhatikan upaya pemenuhan gizi karena kejadian gizi buruk dapat terjadi pada usia tersebut ${ }^{1}$. Menurut World Health Organization (WHO) usia balita merupakan salah satu kelompok usia yang mendapatkan prioritas utama oleh pemerintah dalam hal upaya perbaikan gizi karena kelompok balita pada usia tersebut masih sangat memerlukan gizi untuk pertumbuhan dan perkembangan. Balita yang kurang gizi mempunyai risiko meninggal lebih tinggi dibandingkan balita yang tidak kurang gizi $^{2}$.

Berdasarkan data kajian sektor tentang Kesehatan Pembangunan Gizi di Indonesia pada Tahun 2019, prevalensi stunting pada anak usia di bawah dua tahun sebesar 29,9 $\%^{3}$. Menunjukkan bahwa masalah gizi anak masih cukup tinggi di masyarakat. Provinsi Maluku Utara menempati urutan keempat provinsi penyumbang masalah gizi pada tahun 2019 dengan persentase $20,9 \%{ }^{4}$.

Data status gizi melalui penimbangan/pengukuran berat badan dan tinggi badan di Kabupaten Halmahera Barat pada tahun 2015 menunjukkan bahwa dari 1.137 balita, balita yang mengalami kurang gizi adalah sebanyak $9,5 \%$, gizi buruk $2,6 \%$ dan balita gizi lebih $0,1 \%$. Guna mengatasi hal tersebut, maka pada tahun 2015 strategi atau program yang dilakukan oleh pemerintah melalui puskesmaspuskesmas di Halmahera Barat adalah dengan memberikan makanan tambahan, pemantauan Jaminan Kesehatan Nasional (JKN) dan peningkatan pelayanan gizi melalui pelatihanpelatihan tatalaksana gizi buruk kepada tenaga kesehatan. Walaupun demikian, hingga tahun 2015 hal ini masih belum berhasil menurunkan angka gizi buruk ${ }^{5}$.

Status gizi pada balita dipengaruhi oleh penyebab langsung dan penyebab tidak langsung. Penyebab langsung yang mempengaruhi status gizi balita adalah asupan gizi yang diperoleh balita dan kejadian infeksi yang dialami oleh balita. Penyebab tidak langsung yang mempengaruhi status gizi balita diantaranya adalah karakteristik ibu, pola asuh, pengetahuan ibu tentang gizi balita dan pelayanan kesehatan ${ }^{6}$. Untuk mengetahui apakah balita mengalami pertumbuhan dan perkembangan secara normal atau tidak, maka perlu dilakukan penilaian tumbuh dan kembang dengan cara mengamati pola tumbuh kembang fisik, salah satunya yaitu mengukur berat badan balita ${ }^{7}$.

\section{Metode}

Penelitian ini menggunakan metode penelitian kualitatif yang bersifat deskriptif. Penelitian ini dilakukan pada bulan Desember 2019 sampai Januari 2020. Riset informan dalam penelitian ini adalah perawat dan ahli gizi dari 5 puskesmas di wilayah kerja Halmahera Barat yaitu Puskesmas Kota Jailolo, Puskesmas Jailolo, Puskesmas Akelamo, Puskesmas Golago, dan Puskesmas Sahu.

Metode pengumpulan data dalam penelitian ini menggunakan data primer yang diperoleh melalui wawancara mendalam (in depth interview). Partisipan dalam penelitian ini berjumlah 15 orang yaitu 1 perawat, 1 ahli gizi dan kepala puskesmas dari ke 5 puskesmas. Pengambilan data dilakukan dengan cara menghubungi masing-masing kepala puskesmas, kemudian mengatur waktu dengan masing-masing partisipan lalu di lakukan wawancara kepada partisipan di 5 puskesmas.

Sebelum penelitian ini dilakukan, peneliti telah mendapatkan ijin penelitian dari Pemerintah Kabupaten Halmahera Barat melalui Badan Kesatuan Bangsa dan Politik Daerah (Kesbangpol) melalui surat keterangan penelitian dengan Nomor: 070/291/BKBPD/XII/2019. Penelitian ini juga lolos etik dari Komite Etik Fakultas Kedokteran dan Ilmu Kesehatan Universitas Kristen Satya Wacana dengan Nomor: 226/PE/KEPK.UKSW/2019.

Hasil wawancara tersebut diolah secara deskriptif berupa kata-kata tertulis atau lisan dengan dilanjutkan dengan kesimpulan. Proses wawancara dilakukan dengan pembuatan panduan wawancara, kemudian setelah di wawancara kepada semua partisipan, dilanjutkan dengan pembuatan kategori- 
kategori dari hasil wawancara tersebut kemudian dilanjutkan dengan penentuan sub tema dari masing-masing kategori yang telah di buat, barulah dilakukan pegolahan hasil dan pembahasan dari kategori-kategori yang telah analisis. Kategori yang dianalisis meliputi status kesehatan dalam meningkatkan kesehatan balita, pendidikan kesehatan, layanan kesehatan dalam meningkatkan status gizi balita, kolaborasi layanan kesehatan dalam meningkatkan status gizi balita dan upaya dalam meningkatkan status gizi balita.

\section{Hasil}

Berdasarkan perolehan data di lapangan, diperoleh hasil penelitian meliputi kolaborasi tim kesehatan, kesehatan balita, pendidikan kesehatan, layanan kesehatan untuk meningkatkan status gizi balita, dan upaya meningkatkan status gizi balita.

\section{Kolaborasi Tim Kesehatan}

Kolaborasi yang dilakukan antara perawat dan ahli gizi, di 5 puskesmas berdasarkan hasil wawancara diperoleh bahwa saat melakukan penanganan masalah gizi balita, perawat hanya terlibat dalam memberikan pemeriksaan seperti penimbangan $\mathrm{BB}$ dan $\mathrm{TB}$ namun tidak melakukan tindakan yang kegizian sama sekali, namun ada juga perawat yang sama sekali tidak terlibat penanganan masalah gizi balita. Kolaborasi yang dilakukan dengan tim kesehatan lainnya tergantung program yang di jalankan. Berikut informasi yang didapat dari partisipan.

"Kolaborasi yang dilakukan antara perawat dan ahli gizi untuk masalah gizi balita hanya penimbangan, memberikan konseling tetapi tidak pada gizi sekali hanya tentang kebersihan lingkungan, dan makanan yang baik, bila ada masalah gizi balita perawat tidak melakukan tindakan yang khusus ke-gizi sehingga untuk masalah gizi langsung ditangani oleh petugas gizi. ("sp.o6)",

"Kolaboasi antara perawat dan ahli gizi tidak ada tindakan yang dilakukan oleh perawat, namun ditempat TFC ada dilakukan kolaborasi dengan perawat seperti ahli gizi yang memberikan formulanya dan perawat yang melakukan pengukuran nadi, suhu dan respirasi. (5G.22),

"Kolaborasi yang dilakukan oleh tim kesehatan untuk kecukupan status gizi balita, hanya melakukan konsultasi dengan dokter, sedangkan dengan perawat jarang dilakukan kolaborasi dalam masalah gizi balita. ${ }^{(46.19)}$ "

Terdapat kolaborasi antara perawat dan ahli gizi, namun hanya sebatas memberikan penyuluhan dan pemeriksaan kesehatan seperti pengukuran berat badan dan tinggi badan, selebihnya dilakukan oleh ahli gizi. Bentuk kerjasama lain yang dilakukan ketika balita mengalami masalah gizi yang dibawah ketempat TFC (Therapeutic Feeding Center) untuk dirawat inap. Pada situasi tersebut, kolaborasi lain yang dilakukan yaitu ahli gizi membuat formula makanan tambahan dan perawat mengukur nadi, suhu dan laju raspirasi. TFC (Therapeutic Feeding Center) yaitu tempat pemulihan bagi balita yang mengalami masalah gizi. Pemeriksaan kesehatan yang dilakukan meliputi Pemberian Makanan Tambahan (PMT), penimbangan antropometri, pemberian formula ${ }^{11}$. Kerjasama dengan tim lainnya hanya dilakukan pemeriksaan oleh dokter dan perawat bila ada penyakit penyerta. Perawat sebagai pemberian asuhan seperti tindakan mendampingi serta membantu meningkatkan dan memperbaiki mutu kesehatan diri melalu proses perawatan dalam masalah kesehatan ${ }^{12}$. Hubungan kerjasama antara perawat dengan tenaga kesehatan yang lain sangatlah penting dalam meningkatkan mutu kesehatan. Anggarawati menyatakan bahwa hubungan antara perawat dengan dokter maupun tenaga kesehatan lain dapat menentukan kualitas dalam melakukan kolaborasi ${ }^{7}$.

\section{Status Kesehatan dan Dukungan Meningkatkan Kesehatan Balita}

Kesehatan balita dalam hal ini terkait dengan pertumbuhan balita adalah cukup baik, namun masih ada beberapa yang mengalami masalah gizi balita yang disebabkan oleh pola asuh ibu yang kurang baik, dan adanya penyakit penyerta seperti flu. Masalah yang dihadapi dalam upaya peningkatan status gizi balita, adalah masih kurangnya partisipasi masyarakat untuk terlibat dalam melakukan kegiatan seperti 
posyandu. Menurut partisipan, masih ada balita yang tidak dibawah oleh orangtua untuk mengikuti posyandu sehingga, dukungan yang diberikan untuk meningkatkan status gizi balita dari ke 5 puskesmas, yaitu pemberian PMT seperti susu, kacang hijau, dan biskuit. Dukungan lain yang diberikan berupa pemantauan status gizi melalui penimbangan berat dan tinggi badan. Berikut informasi yang didapat dari partisipan.

"Pertumbuhan balita cukup baik, namun dilihat lagi dari gizinya, ada yang pertumbuhan gizinya terhambat, karena adanya faktor yang menyebabkan penyakit biasanya penyakit infeksi seperti flu, dan biasanya pola asuh ibu untuk balita yang kurang baik. ${ }^{(16.03)}$ ",

"Hambatan yang dialami ketika pada saat melakukan penimbangan ada balita tidak ada ditempat atau sedang keluar daerah sehingga tidak dapat dipantau status gizi balita, dan pada saat melakukan posyandu ada balita yang tidak datang untuk melakukan penimbangan. ${ }^{(46.17) "}$

"Dukungan yang diberikan dalam bentuk pemberian makanan tambahan (PMT) seperti susu dan kacang hijau, terutama pada balita yang selama 3 bulan masa pengamatannya tidak menunjukkan adanya peningkatan $B B$ yang signifikan. $(\mid P .01)$,

Berdasarkan penjelasan di atas, terkait pertumbuhan balita terdapat faktor-faktor tertentu yang dapat menyebabkan pertumbuhan balita terhambat yaitu pola asuh orang tua yang kurang baik, dan adanya penyakit penyerta. Hal tersebut sesuai dengan penelitian Irianti (2018), bahwa faktor penyebab masalah gizi balita yaitu penyakit infeksi, jenis pangan, sosial ekonomi, pendidikan, pola asuh yang kurang baik, sanitasi lingkungan yang kurang baik ${ }^{13}$. Posyandu adalah salah satu pendekatan yang tepat untuk meningkatkan status gizi balita. Kegiatan penimbangan balita merupakan salah satu program dalam upaya perbaikan gizi. Penimbangan balita penting dilakukan setiap satu bulan sampai lima tahun di posyandu untuk mengetahui tumbuh kembang balita ${ }^{14}$. Masalah yang sering dihadapi dalam penerapan posyandu adalah kurangnya partisipasi masyarakat karena, kerap ditemui adanya masyarakat yang keluar daerah dan tidak dapat mengikuti posyandu. Muliah (2018) menyatakan bahwa ibu balita yang jarang mengikuti posyandu akan kurang mendapatkan informasi tentang status gizi balita, sedangkan bila ibu balita rutin mengikuti posyandu ibu dapat memantau pertumbuhan balita ${ }^{15}$. Selain pemantauan status gizi, Pemberian Makanan Tambahan (PMT) merupakan dukungan peningkatan status gizi balita yang bisa diakses melalui kegiatan posyandu. PMT merupakan pemberikan suplemen gizi dalam bentuk makanan tambahan dengan formula khusus dan vitamin sebagai tambahan selain makanan utama sehari-hari guna memenuhi kebutuhan gizi untuk mengatasi kekurangan gizi ${ }^{16}$.

\section{Pendidikan Kesehatan}

Saat melakukan kigiatan untuk meningkatkan status gizi balita, pendidikan kesehatan yang kerap diberikan kepada orangtua berupa penyuluhan tentang ASI eksklusif. Selain tentang ASI eksklusif, materi penyuluhan yang diberikan berupa pola makan yang baik bagi ibu hamil dan balita. Berikut informasi yang didapat dari partisipan.

"Tindakan yang diberikan kepada orangtua untuk pendidikan kesehatan balita dalam meningkatkan status gizi dilakukan peyuluhan tentang ASI ekslusif setiap posyandu. (1P.12)",

"penyuluhan yang diberikan ASI ekslusif, pola makan dimana untuk umur 7 sampai 8 bulan diberikan bubur tetapi yang sudah dihaluskan/saring dan untuk umur 1 tahun sampai 2 tahun bisa diberikan bubur dan nasi tetapi tidak terlalu keras, kemudian menu-menu makanan yang baik untuk balita dan ibu hamil. (4P.11),"

Berdasarkan penjelasan yang diberikan oleh partisipan, pendidikan yang diberikan kepada orangtua untuk meningkatkan status gizi balita diberikan melalui penyuluhan kesehatan. Menurut Notoatmodjo (2010), penyuluhan dapat meningkatkan pengetahuan dan sikap seseorang. Materi yang diberikan dapat berupa pemberian ASI eksklusif dan pola makan yang baik untuk ibu hamil dan balita. Pemberian ASI sendiri dapat meningkatkan pertumbuhan dan perkembangan balita jika diberikan secara ekslusif selama 6 bulan ${ }^{17}$. 
Layanan Kesehatan untuk Meningkatkan Satus Gizi Balta

Perencanaan layanan kesehatan yang dilakukan sebelum program yang telah dibuat dijalankan, dinamakan (POA) " Plan Of Action", direncanakan pada awal tahun untuk program yang akan dijalankan selama 1 tahun dan ada evaluasi di setiap bulannya. Program yang dilakukan berupa penimbangan, dan pemberian makanan tambahan. Untuk pemeriksaan yang dilakukan ada pengukuran berat badan dan tinggi badan. Berikut informasi yang didapat dari partisipan.

"Perencanaan yang dilakukan pada awal tahun istilahnya dari puskesmas POA "plan of action" perencanaannya tentang muatan pekerjaan dimana rencana awal tahun dan akhir tahun dilakukan oleh puskesmas yang direncanakan dalam setiap program sesuai dengan target yang telah ditentukan oleh dinas kesehatan. (1K.08)"

"Perencanaan yang dilakukan sebelum kegiatan dilakukan evaluasi setiap bulannya jadi puskesmas setiap bulan melakukan evaluasi yang biasanya disebut mini lokakarya, dan koordinasi untuk melakukan evaluasi program gizi dan program kebidanan yaitu posyandu, keadaan gizi masyarakat dalam perencanaan akan dibahas tentang hasil pemantauan posyandu, dan perkembangan kesehatan balita, setelah itu dilakukan evaluasi untuk melanjutkan kegiatan dibulan berikutnya, jadi setiap bulannya dilakukan evaluasi dan pemantauan. (5K.06)"

"Program rutin yang dilakukan hanya imunisasi dan penimbangan. (4P.0.5)"

"Program khusus yang dilakukan diberikan PMT pemulihan selama 3 bulan. ${ }^{(56.05)}$ "

"Pemeriksaan yang dilakukan untuk meningkatkan status gizi balita dilakukan penimbangan tinggi badan dan berat badan kemudian tiap 6 bulan diberikan obat cacing. (4P.07)",

Berdasarkan informasi yang diberikan oleh partisipan, sebelum melakukan layanan kesehatan, dilakukan perencanaan diawal tahun untuk program yang akan dijalankan selama 1 tahun, yang dinamakan POA setelah dilakukan perencanaan barulah dibagi programnya perbulan sesuai dengan kegiatan yang akan dilakukan. Perencanaan merupakan salah satu fungsi manejeman kesehatan, yang dilakukan oleh puskesmas dalam upaya mewujudkan keberhasilan suatu program dengan baik ${ }^{18}$. Evaluasi dilakukan setiap bulannya untuk melihat perkembangan dari program yang dijalankan (mini lokakarya). Program yang dilakukan untuk meningkatkan status gizi yaitu diberikan PMT kepada balita. Program PMT sangat berpengaruh terhadap status gizi balita dimana kualitas makanan yang diberikan sesuai dengan kebutuhan dalam meningkatkan status gizi balita ${ }^{16}$. Pemeriksaan yang dilakukan seperti penimbangan berat badan dan tinggi badan. Pengukuran berat badan dan tinggi badan juga merupakan indeks yang paling sering digunakan untuk mengevaluasi keadaan status $^{19}$.

\section{Upaya Meningkatkan Status Gizi Balita}

Beberapa upaya yang dilakukan untuk meningkatkan status gizi balita adalah dengan memberikan penyuluhan mengenai pola makan sehat dan pemberian makanan tambahan. Upaya lain adalah dengan melakukan pendekatan kepada orangtua balita, agar secara rutin memantau kesehatan balita dengan cara datang ke Posyandu untuk melakukan penimbangan tinggi dan berat badan. Berikut informasi yang didapat dari partisipan.

"Evaluasi yang diberikan untuk meningkatkan status gizi balita diberikan penyuluhan tentang pola makan untuk balita, setelah diberikan penyuluhan bulan berikutnya di periksa apakah ibu balita melakukan sesuai dengan penyuluhan bulan kemarin atau tidak barulah dipantau berat badan dan dilihat peningkatan dari menu makanan makanan yang diberikan ibu balita. (4P.14)," "Evaluasi yang dilakukan diberikan PMT, penyuluhan dan konseling. (2G.17)",

"Upaya yang dilakukan untuk mengatasi masalah yang dialami diberikan PMT dari puskesmas, jadi bila ada yang mengalami masalah gizi langsung ditangani oleh petugas gizi diberi makanan tambahan dan di antarkan ke rumah. ${ }^{(4 P .16)}$," 
"Upaya yang dilakukan untuk mengatasi masalah dengan melakukan pedekatan. (1P.19)",

Dari informasi yang didapat dari pertisipan terkait upaya dalam meningkatkan status gizi balita yaitu diberikan penyuluhan dan konseling terkait pola makan yang sehat untuk balita dan kepada orangtua, serta upaya yang di berikan PMT seperti susu, kacang hijau dan biskut. Dalam mencapai status gizi balita yang baik tidak terlepas dari peran orangtua yang bertanggung jawab dalam pemberian makanan kepada keluarga termasuk untuk balita. Peran keluarga sangat berpengaruh dalam masalah gizi balita Karena pola makan maupun kebiasan makan balita tergantung pada pola makan keluarga, Selain itu balita juga masih sangat tergantung pada keluarga terutama dalam pemenuhan asuhan kebutuhan gizinya ${ }^{20}$.

\section{Kesimpulan}

Berdasarkan hasil penelitian yang dilakukan di 5 Puskesmas yang berada di Halmahera Barat dapat disimpulkan bahwa terdapat kolaborasi yang dilakukan antara perawat dan ahli gizi dalam penanganan masalah gizi balita, namun hanya sebatas pada pemeriksaan tanda - tanda vital dan membantu menyalurkan atau memberikan Pemberian Makanan Tambahan (PMT) pada balita. Sebagian besar kegiatan terkait masalah gizi balita dilakukan oleh ahli gizi dan untuk perawat hanya sebatas pemeriksaan vital.

\section{Ucapan Terima Kasih}

Terima kasih kepada Kepala Dinas Kesehatan Kabupaten Halamahera Barat, serta kepada 5 Kepala Puskesmas yang berada di Wilayah Kerja Kabupaten Halmahera Barat yang memberikan izin untuk melakukan penelitian ini dan juga kepada partisipan yang telah meluangkan waktunya untuk penelitian ini.

\section{Daftar Pustaka}

1. Sujana T, Nugroho KPA, Sianturi MRW. 2019. Peran Posyandu Dalam Pemberian Promosi Kesehatn Halmahera Utara.
Jurnal Kesehatan Bakti Tunas Husada. 19:80-92.

2. Herlina S. 2018. Hubungan Pengetahuan dan Pendidikan Ibu terhadap Status Gizi Balita. Jurnal Kesehatan masyarakat. 1(1).

3. Kementerian PPN/Bappenas. 2019. Kajian Sektor Kesehatan Pembangunan Gizi Di Indonesia..

4. Prabhakara G. 2019. Profil-Kesehatanindonesia. Health Statistics (Health Information System). doi:10.5005/jp/books/11257_5

5. Dagasuly MI, Kapantow NH, Kekenusa JS. 2017. Analisis Pelaksanaan Program Gizi Seimbang Kesehatan Kabupaten Halmahera Barat. Kesehatan Masyarakat Universitas Sam Ratulang. 117-135.

6. Muharry A, Kumalasari I, Dewi ER. 2017. Faktor Yang Mempengaruhi Status Gizi Balita Di Puskesmas Nelayan Kota Cirebon. JI-KES (Jurnal Ilmu Kesehatan). 1(1):25-33. doi:10.33006/jikes.v1i1.41

7. Kurniasaria MD, Nugroho KPA, Rantya SY. 2019. Kolaborasi Perawat dan Ahli Gizi di Posyandu Balita Puskesmas Jetak, Kabupaten Semarang. Jurnal Ilmu Keperawatan dan Kebidanan. 10(1):123129.

8. Judistiani RTD, Fauziah A, Astuti S, Yuliani A, Sari P. 2015. Gangguan Gizi Balita di Desa Mekargalih Kecamatan Jatinangor - Sumedang: Masalah Kesehatan Masyarakat. Jurnal Sains dan Kesehatan. 1(38):84-91.

9. Andini V, Sabrian F, Nauli FA. 2014. Peran Perawat Perkesmas Tentang Peran Perawat Sebagi edukator di Puskesmas Se-kota Pekanbaru. Jurnal Online mahasiswa. 268-277.

10. Kemenkes Maluku Utara. 2017. Data Dasar Puskesmas. Vol 53.; doi:10.1017/CBO9781107415324.004

11. Rakhma LR, Erlinda F, Apriliana WF. 2017. Hubungan Tingkat Pendidikan 
dengN Pengetahuan Ibu Balita pada program Therapeutic Feeding Center (TFC) di Sukoharjo Jawa Tengah. Preventif: Jurnal Kesehatan Masyarakat. 2:66-72.

12. Wahyudi I. 2020. Pengalaman Perawat Menjalani Peran dan Fungsi Perawat di Puskesmas Kabupaten Garut. Jurnal Sahabat Keperawatan. 2(1):36-43. https://jurnal.unimor.ac.id/JSK.

13. Irianti B. 2018. Faktor- Faktor Yang Menyebabkan Status Gizi Kurang Pada Balita Di Wilayah Kerja Puskesmas Sail Pekanbaru Tahun 2016. Midwifery J J Kebidanan UM Mataram. 3(2):95. doi:10.31764/mj.v3i2.478

14. Simbolon DT. 2020. Hubungan Jumlah Kunjungan Ibu Ke Posyandu Dengan Status Gizi Balita Di Wilayah Kerja Puskesmas Amplas. Jurnal Keperawatan Priority.3(2):31-41. doi:10.34012/jukep.v3i2.958

15. Muliah N, Wardoyo AS, Mahmudiono T. 2018. Hubungan Frekuensi Penimbangan, Penggunaan Garam Beryodium, Dan Pemberian Vitamin a Dengan Kejadian Underweight Pada Balita Di Provinsi Jawa Timur. Media Gizi Indonesia. 12(1):40. doi:10.20473/mgi.v12i1.40-46

16. BalitaSetiowati KD, Budiono I. 2019. Perencanaan Program Pemberian Makanan Tambahan Pemulihan untuk Balita. HIGELA Journal Of Public Health Research And Development. 3(1):109-120.

17. Soamole R, Asnaniar WOS, Taqiyah Y, Sharief SA. 2018. Hubungan Antara Pemberian Asi Eksklusif Dengan Perkembangan Bahasa Anak Usia 12-36 Bulan Di Puskesmas Tamamaung Makassar. Jurnal Islam Nurs. 3(2):30. doi:10.24252/join.v3i2.6803

18. Susanti EM, Handayani OWK, Raharjo BB. 2017. Implementasi Penatalaksanaan Kasus Gizi Buruk Di Wilayah Kerja Puskesmas Cilacap Utara I. Unnes Jurnal
Public Heal. $\quad$ 6(1):47. doi:10.15294/ujph.v6i1.11726

19. Rusdiarti. 2019. Analisis Pengukuran Ketepatan Antropometri Tinggi badan Balita Pada pelaatihan Kader Posyandu di Panduman Kecamatan Jelbuk. HIJP: Health Information Jurnal Penelitian. 11.2 .

20. Kusumawardani LH. 2020. Peningkatan Pengetahuan Gizi Seimbang pada Ibu Balita Melalui Edukasi dan Simulasi Pembuatan Makanan Bergizi di Desa Kebumen, Baturraden. Jurnal of Bionursing. 2(1):9-14. http://bionursing.fikes.unsoed.ac.id/bion/ index.php/bionursing/article/view/32/49. 